\title{
Acquired del(9)(p22.3) in a primary plasma cell leukemia
}

\author{
Walid Al Achkar ${ }^{1 *}$, Abdulsamad Wafa', Abdulmunim Aljapawe², Moneeb Ak Othman³, Eyad Alhourani \\ and Thomas Liehr ${ }^{3}$
}

\begin{abstract}
Background: Plasma cell leukemia $(\mathrm{PCL})$ is a rare lymphoproliferative disorder, accounting for $1-2 \%$ of all plasma cell neoplasms, characterized by the presence of $>2 \times 10^{9} / \mathrm{I}$ of plasma cells circulating in the peripheral blood, and exists in two forms: primary PCL (pPCL, 60\% of the cases), and secondary PCL (sPCL), the latter being a leukemic transformation in patients with a previously diagnosed multiple myeloma. $P C L$ is an aggressive disease with poor prognosis and a short median survival of 7 months.
\end{abstract}

Results: Here, we report a PPCL case with hepatosplenomegaly, anemia, thrombocytopenia, fever, fatigue, weight loss, and plasma cell count up to 60\% in peripheral blood and $80 \%$ in bone marrow. Immunophenotype was compatible with PCL. A del(9)(p22.3) was characterized using banding cytogenetics and array-proven multicolor banding (aMCB), the latter being of enormous significance to characterize breakpoint regions in detail.

Conclusion: To the best of our knowledge, this is the first report of $\mathrm{PPCL}$ associated with a partially monosomy 9pter to 9p22.3 as a sole chromosomal abnormality.

Keywords: Primary plasma cell leukemia, Multiple myeloma, Del(9)(p22.3), Array-proven multicolor banding, Prognostic factors

\section{Background}

Plasma cell leukemia (PCL) is a rare lymphoproliferative disorder, accounting for 1-2\% of all plasma cell neoplasms [1]. It is defined by the presence of more than $20 \%$ plasma cells in peripheral blood and an absolute plasma cell count greater than $2 \times 10^{9} / \mathrm{L}$ [1]. PCL can be classified into two types. The primary form (pPCL), it occurs de novo in the absence of a prior history of multiple myeloma (MM) and it presents in $60 \%$ of PCL cases, and a secondary form (sPCL) with a history of plasma cell myeloma (PCM) which have progressed to a leukemic phase [1,2].

Clinically, patients with primary PCL have a higher incidence of hepatosplenomegaly and lymphadenopathy, and less lytic bone lesions [3]. Prognostic indexes such as B2-microglobulin, plasma cells in S-phase, proteinuria, calcium levels, LDH and renal function usually are found to be significantly higher in PCL than in MM [2].

\footnotetext{
* Correspondence: ascientific@aec.org.sy

${ }^{1}$ Department of Molecular Biology and Biotechnology, Human Genetics Division, Atomic Energy Commission, P.O. Box 6091, Damascus, Syria Full list of author information is available at the end of the article
}

PCL is highly aggressive, with unsatisfactory responses to therapy, a poor prognosis, and a median survival of 7 months [2]. Due to the low frequency of this entity, most publications on PCL are based on case reports, only a few series exist with more than 20 patients in the medical literature, and difficulties remain in defining the biological, clinical, and prognostic features of the disease $[2,3]$.

Here we reported a new case of pPCL with a del(9) (p22.3), which was characterized by array-proven multicolor banding (aMCB); also the case had an immunophenotype result consistent with PCL.

\section{Methods}

\section{Case report}

A 57-year-old male was diagnosed as suffering from pPCL. Hepatosplenomegaly, anemia, thrombocytopenia, fever, fatigue, and weight loss were the indicative symptoms. His hematologic parameters were: white blood cells (WBC) of $2.7 \times 10^{9} / 1$ with $60 \%$ plasma cells, red blood cell (RBC) count was $3.48 \times 10^{6} / \mathrm{mm}^{3}$, hemoglobin level was $10.6 \mathrm{~g} / \mathrm{dl}$ and the platelet count was $67 \times 10^{9} / \mathrm{l}$. The serum creatinine was $1.07 \mathrm{mg} / 100 \mathrm{ml}$ (normal level 
up to $1.5 \mathrm{mg} / 100 \mathrm{ml}$ ); calcium, $8.5 \mathrm{mg} / 100 \mathrm{ml}$ (normal level up to $10.2 \mathrm{mg} / 100 \mathrm{ml}$ ); serum lactate dehydrogenase (LDH) level was $662 \mathrm{U} / \mathrm{l}$ (normal level up to $480 \mathrm{U} / \mathrm{l}$ ); serum aspartate aminotrasferase (AST) level was $42 \mathrm{U} / \mathrm{l}$ (normal up to $40 \mathrm{U} / \mathrm{l}$ ); and serum 32 -microglobulin level was $4.12 \mathrm{mg} / \mathrm{l}$ (normal level up to $2.3 \mathrm{mg} / \mathrm{l}$ ). Total serum protein was within normal range at $7.3 \mathrm{gm} / \mathrm{dl}$ (normal value $6-8.5 \mathrm{gm} / \mathrm{dl}$ ) but serum albumin was $3.4 \mathrm{gm} / \mathrm{dl}$ (normal value $3.8-5 \mathrm{gm} / \mathrm{dl}$ ); serum IgG level was $812 \mathrm{mg} /$ $\mathrm{dl}(700-1600 \mathrm{mg} / \mathrm{dl})$; serum IgA level was $140 \mathrm{gm} / \mathrm{dl}$ (70-400 $\mathrm{mg} / \mathrm{dl}$ ); and serum IgD level was $48.9 \mathrm{mg} / \mathrm{dl}$ $(40-230 \mathrm{mg} / \mathrm{dl})$. Bone marrow aspiration revealed an $80 \%$ of plasma cells. No treatment had been administered prior to the test.

All human studies have been approved by the ethics committee of the Atomic Energy Commission, Damascus, Syria and have therefore been performed in accordance with the ethical standards laid down in the 1964 Declaration of Helsinki and its later amendments. The patient gave his informed consent prior to its inclusion in this study.

\section{Chromosome analysis}

Chromosome analysis using GTG-banding was performed according to standard procedure prior chemotherapeutic treatment [4]. A total of 20 metaphase cells derived from unstimulated bone marrow culture were analyzed. Karyotypes were described according to the International System for Human Cytogenetic Nomenclature (ISCN) [5].

\section{Molecular cytogenetics}

FISH using a chromosome-9-specific aMCB probe set based on microdissection derived region-specific libraries was done as previously reported [4]. Also paints for whole chromosomes 11 and 14 (wcp-probes) were applied (MetaSystems, Altlussheim, Germany) according to manufacturer's instructions. A total of 20 metaphase spreads were analyzed, each using a fluorescence microscope (AxioImager.Z1 mot, Zeiss) equipped with appropriate filter sets to discriminate between a maximum of five fluorochromes plus the counterstain DAPI (4',6-diamino-2-phenylindole). Image capturing and processing were carried out using an ISIS imaging system (MetaSystems, Altlussheim, Germany).

\section{Flow cytometric immunophenotype}

Immunophenotyping was performed according to [6]. Manufacturer's instructions (BD Biosciences) were also considered. Flow cytometric analysis was performed using a general panel of fluorescent antibodies against the following antigens typical for different cell lineages and cell types: CD1a, CD2, CD3, CD4, CD5, CD8, CD10, CD11b, CD11c, CD13, CD14, CD15, CD16, CD19, CD20, CD22, CD23, CD32, CD33, CD34, CD38, CD41a, CD45, CD56, CD57, CD64, CD103, CD117, CD123, CD138, CD209, CD235a and CD243; In addition to antibodies to Kappa and Lambda light Chains, IgD, sIgM, and HLADr. All antibodies purchased from BD Biosciences. Samples analyzed on a BD FACSCalibur ${ }^{\mathrm{mt}}$ flow cytometer. Autofluorescence, viability, and isotype controls were included. Flow cytometric data acquisition and analysis conducted by BD Cellquest ${ }^{\mathrm{Tm}}$ Pro software. Interpretations of flow cytometric results were according to [7].

\section{Results}

Pathology results showed that bone marrow specimen had very high cellularity. Bone marrow consisted of a morphologically homogenous abnormal cell population having plasma cell features.

Prior to chemotherapy treatment banding in cytogenetics revealed a karyotype 46,XY[12]/46,XY,del(9)(p?)[8]

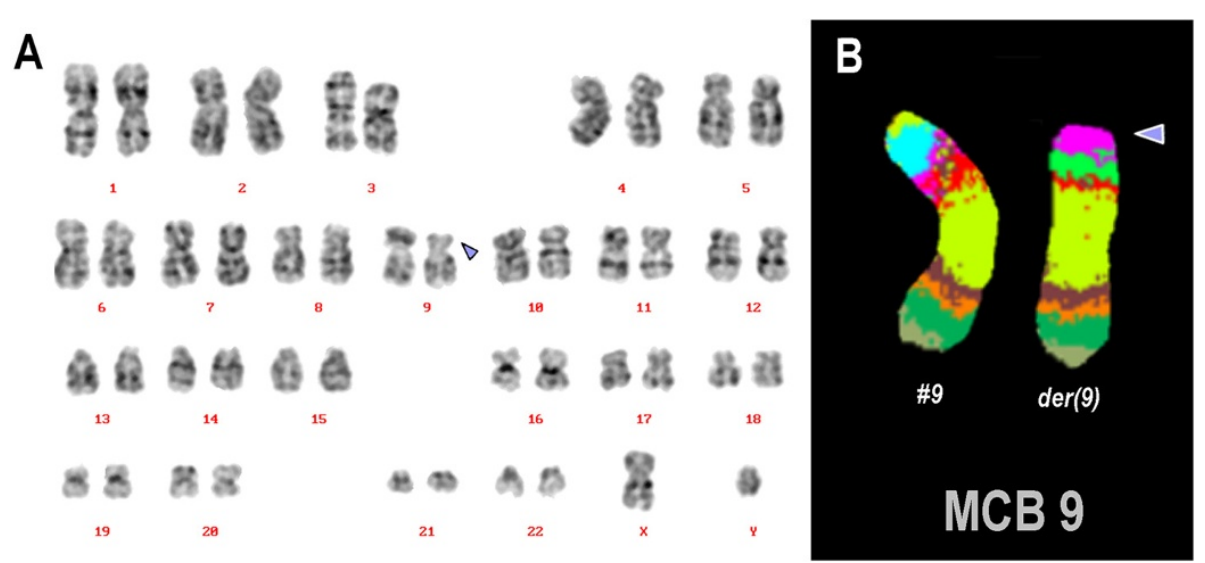

Figure 1 Cytogenetics and molecular cytogenetics results. (A). GTG-banding revealed a del(9)(p22.3). The derivative chromosome is highlighted by arrow head. (B). The application of $\mathrm{aMCB}(9)$ characterized the del(9)(p22.3) comprehensively. Abbreviations: \# = chromosome; der $=$ derivative chromosome. 
(Figure 1A). An aMCB using a specific probe for chromosome 9 revealed a deletion a part of short arm of chromosome 9 was present (Figure 1B). The final karyotype was determined as: 46,XY[12]/46,XY,del(9)(p22.3)[8] as a $\mathrm{t}(11 ; 14)(\mathrm{q} 13 ; \mathrm{q} 32)$ could be excluded using wcp probes (results not shown).

The abnormal cell population showed the following immunophenotype: $\mathrm{CD} 45^{+\mathrm{dim}}(80 \%), \mathrm{HLADr}^{+}(78 \%), \mathrm{CD}^{+} 0^{+}$ (80\%), CD $38^{\text {bright }}$ (88\%), $\mathrm{CD} 22^{+}(64 \%), \mathrm{CD}^{\mathrm{b}} 17^{+}(73 \%)$, $\mathrm{CD}^{+} 9^{+}(80 \%), \mathrm{CD}^{+} 0^{+}(64 \%), \mathrm{CD}^{+} 2^{+}(63 \%)$ and expressed CD13 (16\%), CD138 (30\%), CD15 (24\%), sIgM (52\%) heterogeneously. This population negatively reacted with antibodies to CD34, CD243, CD16, CD56, CD2 CD3, CD5, CD23, CD11c and CD103. CD138 expression was heterogeneous; although abnormal cell population represented $80 \%$ of all cells in lymphocytes gate, only $30 \%$ of those were CD138 positive. Expression of surface IgM was dim and heterogeneous; only $52 \%$ of abnormal cells in the lymphocytes gate reacted positively with mouse antihuman IgM (isotype IgG1-Kappa, clone G20-127). Overall, this immunophenotype was mostly consistent with PCL [7].

\section{Discussion}

PCL is a rare entity; we described a case of PPCL with a de novo del(9)(p22.3). To the best of our knowledge, the present case is the only one ever seen with this kind of aberration [8].

According to the literature, the plasma cells have a characteristic phenotype: Strong expression of CD38 and CD19 and weak expression of CD56. In contrast to normal plasma cells, myeloma cells are often immature and may have the plasmablastic appearance [9]. While the expression of CD19 is usually negative, myeloma cells express CD56 antigen strongly along with CD38 [10].

Plasma cells in PCL display a more immature phenotype than in MM, as to be assessed by expression of CD20 antigen, the latter being usually absent in MM [11]. In addition plasma cells in PCL frequently lack CD56 antigen, which has been considered important in anchoring plasma cells to bone marrow stroma [12]. Immunophenotypic expression is similar in PCL and MM for CD38, CD138, CD2, CD3, CD6, CD10, CD13 and CD15 [3]. The phenotypic differences do not allow a complete discrimination between PCL and MM, but help to explain the differences in survival, since CD56 expression has been associated with good prognosis while CD20 expression has been associated with a shorter survival [13].

Recent attempts at genetic and molecular profiling of PCL have provided important clues to its biology. Using karyotyping, cytogenetic abnormalities have been identified in over $70 \%$ of PCL patients. Hypodiploidy and complex karyotypes with multiple numerical and structural abnormalities involving chromosome 1, 13, and 14 have been identified in a significant number of PCL cases [14]. Molecular genetic abnormalities including del(13q), del (17p), $\mathrm{t}(11 ; 14), \mathrm{t}(4 ; 14), \mathrm{t}(4 ; 16) \mathrm{del}(1)(\mathrm{p} 21)$, and $1 \mathrm{q} 21-$ amplifications have been reported $[1,14]$.

Primary PCL has a more aggressive course high frequency of extramedullary involvement (liver, spleen, lymph nodes, extra osseous plasmacytomas etc.), thrombocytopenia, anemia, hypercalcemia and impaired renal function [3]. PCL displays multiple adverse prognostic indicators at presentation such as elevated LDH, elevated $ß 2$-microglobulin, hypercalcemia, high percentage of Bence-Jones proteinemia, and extramedullary involvement [13].

The prognosis for pPCL is unfavorable, with a median overall survival of 7 months [2]. In preceding reports, the unfavorable prognostic risk factors were a lack of response to treatment, the increased levels of $\mathrm{LDH}$, and the peripheral plasma cell count [15]. Deletions in 9p are found in about $9 \%$ of cases of adult acute lymphoblastic leukemia. The prognostic impact of deletions in 9p has been discussed controversial [16].

In conclusion, we reported a de novo case of pPCL with a new cytogenetic abnormality, a partial monosomy 9pter to 9p22.3. Overall this finding may be regarded as unfavorable prognostic parameter in PCL, however, it could not be confirmed in the present case, as the patient was lost during follow-up.

\section{Competing interests}

The authors declare that they have no competing interests.

\section{Authors' contributions}

WA-A, AA and AW provided the case and/or did primary cytogenetic and main part of the FISH-tests and flowcytometry; MAKO,EA and TL did detailed FISH studies. WA drafted the paper and all authors read and approved the final manuscript.

\section{Acknowledgements}

We thank Prof. I. Othman, the Director General of Atomic Energy Commission of SYRIA (AECS) and Dr. N. Mirali, Head of Molecular Biology and Biotechnology Department for their support. This work was supported by the AECS, and in parts by the Stefan-Morsch-Stiftung.

\section{Author details}

'Department of Molecular Biology and Biotechnology, Human Genetics Division, Atomic Energy Commission, P.O. Box 6091, Damascus, Syria. ${ }^{2}$ Department of Molecular Biology and Biotechnology, Mammalians Biology Division, Atomic Energy Commission, Damascus, Syria. ${ }^{3}$ Jena University Hospital, Institute of Human Genetics, Jena, Germany.

Received: 27 June 2013 Accepted: 24 July 2013

Published: 28 August 2013

\section{References}

1. Cho SY, Lim G, Oh SH, Lee HJ, Suh JT, Lee J, Lee WI, Lee HG, Yoon HJ, Park TS: Primary plasma cell leukemia associated with $\mathrm{t}(6 ; 14)(\mathrm{p} 21 ; \mathrm{q} 32)$ and IGH rearrangement: a case study and review of the literature. Ann Clin Lab Sci 2011, 41:277-281.

2. Jimenez-Zepeda VH, Dominguez-Martinez VJ: Plasma cell leukemia: a highly aggressive monoclonal gammopathy with a very poor prognosis. Int J Hematol 2009, 89:259-268. 
3. Naseem S, Kaur S, Gupta R, Kashyap R, Nityanand S: Plasma Cell Leukemia: case series from a tertiary center with review of literature. Indian J Hematol Blood Transfus 2012, 28:10-14.

4. Al Achkar W, Wafa A, Klein E, Aljapawe A: Biclonal myelodysplastic syndrome involving six chromosomes and monoallelic loss of RB1 A rare case. Mol Cytogenet 2011, 4:16.

5. ISCN, Shaffer LG, Slovak ML, Cambell LJ: International System for Human Cytogenetic Nomenclature 2009. Basel: S Karger AG; 2009.

6. Stewart CC, Stewart SJ: Current protocols in Cytometry, Unit 6.2.1-6.2.18, John Wiley \& Sons: Inc. 1997.

7. Craig FE, Foon KA: Flow cytometric immunophenotyping for hematologic neoplasms. Blood 2008, 111:3941-3967.

8. Van Camp B, Durie BG, Spier C, De Waele M, Van Riet I, Vela E, Frutiger Y, Richter L, Grogan TM: Plasma cells in multiple myeloma express a natural killer cell-associated antigen: CD56 (NKH-1; Leu-19). Blood 1990, 76:377-382.

9. Mitelman F, Johansson B, Mertens F: Mitelman Database of Chromosome Aberrations in Cancer. 2013. http://cgap.nci.nih.gov/Chromosomes/Mitelman.

10. Bataille R, Harousseau JL: Multiple myeloma. N Eng J Med 1997, 336:1657-1664.

11. Cook G, Dumbar M, Franklin IM: The role of adhesion molecules in multiple myeloma. Acta Haematol 1997, 97:81-89.

12. Ruiz-Arguelles GJ, San Miguel JF: Cell surface markers in multiple myeloma. Mayo Clin Proc 1994, 69:684.

13. García-Sanz R, Orfão A, González M, Tabernero MD, Bladé J, Moro MJ, Fernández-Calvo J, Sanz MA, Pérez-Simón JA, Rasillo A, Miquel JF: Primary plasma cell leukemia: clinical, immunophenotypic, DNA ploidy, and cytogenetic characteristics. Blood 1999, 93:1032-1037.

14. Sher T, Miller KC, Deeb G, Lee K, Chanan-Khan A: Plasma cell leukaemia and other aggressive plasma cell malignancies. Br J Haematol 2010, 150:418-427.

15. Pagano L, Valentini CG, De Stefano V, Venditti A, Visani G, Petrucci MT, Candoni A, Specchia G, Visco C, Pogliani EM, Ferrara F, Galieni P, Gozzetti A, Fianchi L, De Muro M, Leone G, Musto P, Pulsoni A, GIMEMA-ALWP (Gruppo Italiano Malattie EMatologiche dell'Adulto, Acute Leukemia Working Party: coordinator Sergio Amadori): Primary plasma cell leukemia: a retrospective multicenter study of 73 patients. Ann Oncol 2011, 22:1628-1635

16. Mancini M, Scappaticci D, Cimino G, Nanni M, Derme V, Elia L, Tafuri A, Vignetti M, Vitale A, Cuneo A, Castoldi G, Saglio G, Pane F, Mecucci C, Camera A, Specchia G, Tedeschi A, Di Raimondo F, Fioritoni G, Fabbiano F, Marmont F, Ferrara F, Cascavilla N, Todeschini G, Nobile F, Kropp MG, Leon P, Tabilio A, Luppi M, Annino L, Mandelli F, Foà R: A comprehensive genetic classification of adult acute lymphoblastic leukemia (ALL): analysis of the GIMEMA 0496 protocol. Blood 2005, 105:3434-3441.

doi:10.1186/1755-8166-6-33

Cite this article as: Achkar et al.: Acquired del(9)(p22.3) in a primary plasma cell leukemia. Molecular Cytogenetics 2013 6:33.

\section{Submit your next manuscript to BioMed Central and take full advantage of:}

- Convenient online submission

- Thorough peer review

- No space constraints or color figure charges

- Immediate publication on acceptance

- Inclusion in PubMed, CAS, Scopus and Google Scholar

- Research which is freely available for redistribution

Submit your manuscript at www.biomedcentral.com/submit
C Biomed Central 